\title{
ZAGREB NA FILMOVIMA TELEVIZIJE ZAGREB 1956. - 1967.: PROMOCIJA, REPREZENTACIJA I URBANIZACIJA GRADA
}

\section{Mihaela Marić}

UDK: 711.4(497.5 Zagreb):654.197“1956/1967“

Izvorni znanstveni članak

Sažetak: U razdoblju nakon Drugog svjetskog rata Zagreb proživljava promjenu u svim aspektima života, ponajprije zaslugama zagrebačkoga gradonačelnika Većeslava Holjevca, za čijeg je drugog mandata Zagreb „prešao preko Save“. Usporedno s daljnjim urbanim razvojem grada razvija se i Radiotelevizija Zagreb (RTZ), koja svoj put započinje u pedesetim godinama emitiranjem prvog eksperimentalnog programa, a zatim prvog domaćeg programa uživo s otvorenja „Zagrebačkog velesajma“ na novoj lokaciji preko Save. U radu se naglasak stavlja na razmatranje usporednog razvoja Televizije Zagreb te urbanog razvoja grada kako ga je dokumentirala televizija. S obzirom na to da je i u realizaciji urbanog plana i pri osnivanju televizije veliku ulogu igrao Holjevac, pokušat će se promotriti koliko mu se prostora davalo u reportažama te kako se gradonačelnik koristio televizijom za samopromociju.

Ključne riječi: Zagreb, Radiotelevizija Zagreb (RTZ), urbanizacija, industrijalizacija, Većeslav Holjevac, „Velesajam“, Novi Zagreb

\section{UVOD}

(1)

razdoblju nakon Drugog svjetskog rata grad proživljava promjenu u svim aspektima života. Zasluge zagrebačkoga gradonačelnika Većeslava Holjevca, za čijeg je drugog mandata Zagreb „prešao preko Save“, pritom su neosporne i dodatno su ubrzale urbane transformacije. Usporedno s poslijeratnim razvojem grada razvija se i Radiotelevizija Zagreb (RTZ), koja svoj put započinje u pedesetim godinama emitiranjem prvog eksperimentalnog programa, zatim prvog domaćeg programa uživo s otvorenja „Zagrebačkog velesajma“ na novoj lokaciji preko Save do relativnog uzleta u sljedećih dvadesetak godina. Poticajan je, pri proučavanju odnosa televizije i društva, pristup britanskog povjesničara Ase Briggsa, koji 
daje nov način istraživanja povijesti televizije, koristeći se komparativnom metodom i kontekstualizirajući televiziju u društvenim i političkim prilikama toga vremena, izbjegavajući dotadašnju praksu isključivog objavljivanja same građe arhiva televizije. ${ }^{1}$ Istraživanje tako postaje kompleksnije, a televizija kao moderni društveni fenomen bolje razumljiva. Stoga je i u ovom radu naglasak na razmatranju usporednog razvoja Televizije Zagreb i urbanog razvoja grada kako ga je dokumentirala televizija. $S$ obzirom na to da je i u realizaciji urbanog plana i pri osnivanju televizije veliku ulogu igrao Većeslav Holjevac, pokušat će se promotriti koliko mu se prostora davalo u reportažama te kako se gradonačelnik koristio televizijom za samopromociju. Ponajprije će se promotriti neki od važnijih procesa koji su obilježili urbanizaciju Zagreba do 1970. te kako je sve to popratila Televizija Zagreb. Zatim će se analizirati njen razvoj, kako bi se razmotrio međuodnos razvoja televizije i grada te da bi se jasnije shvatilo nastanak i vrste korištene građe iz arhiva HRT-a. Pri samom kraju rada bit će govora o tadašnjem gradonačelniku Holjevcu kao ličnosti koja povezuje oba ova procesa.

Prije same analize potrebno je osvrnuti se na specifičnost korištene građe arhiva Hrvatske radiotelevizije (HRT), na kojoj se temelji ovaj rad, kako bi se ukazalo na mnoge probleme razvoja televizije u razdoblju od njezinih početaka do 1970-ih. Sačuvane informativne emisije (Filmske vijesti i Vijesti) iz prvih godina rijetke su, snimke traju po nekoliko minuta, a prikazuju se kratki crno-bijeli kadrovi, nažalost, najčešće bez zvuka jer audiovrpce nisu sačuvane. Snimke su se u prvim godinama često preuzimale iz Beograda ili su se miješale $s$ vijestima koje su se ondje snimale. Stoga su i snimke koje prate Holjevca i urbani razvoj Zagreba u ovom razdoblju malobrojne, kratke i teško dostupne. Za razdoblje šezdesetih koristile su se emisije Zagrebački tjednik te Jučer, danas, sutra, a zbog manjka izvorne građe i bolje usporedbe koristile su se i emisije iz kasnijih razdoblja, koje su već bile lakše dostupne u boji i s audiosnimkom. Sva dostupna građa analizira se s pomoću komparativne i kvantitativne metode.

\section{INDUSTRIJALIZACIJA I URBANIZACIJA POSLIJERATNOG ZAGREBA}

Zagreb poslije Drugog svjetskog rata potresaju mnogi problemi, koji su usporavali proces urbanizacije i industrijalizacije grada. Ne samo da se morao nositi s posljedicama rata već se susreo i s velikim porastom stanovništva. Jednim dijelom bile su to izbjeglice, koje su svoje utočište potražile u Zagrebu za vrijeme rata pa su onda neke od njih u njemu i ostale, a dijelom do toga dolazi zbog brze industrijalizacije grada. Zagreb je nakon rata najveći trgovački grad Jugoslavije te središte uvozne trgovine, stoga ljudi masovno sa sela odlaze

1 O tome v. Asa Briggs i Peter Burke, Socijalna povijest medija. Od Gutenberga do interneta, Zagreb 2011.; A. Briggs, The History of Broadcasting in the United Kingdom, sv. 1-5, Oxford 1961. - 1995.: The Birth of Broadcasting (1961.), The Golden Age of Wireless (1927-1939) (1965.), The War of Words (1939-1945) (1970.), Sound and Vision (1945-1955) (1979.), Competition (1955-1974) (1995.); Ista, The BBC: The First Fifty Years, Oxford 1986.; Kurt Lang i Gladys Engel Lang, Television and Politics, London 2002.

2 Tomislav Timet, „Prilog poznavanju stambene izgradnje Zagreba“, Iz starog i novog Zagreba, sv. 3 (ur. Franjo Buntak), Zagreb 1963., 275. 
u grad. ${ }^{2}$ No, na njegovu obnovu i razvoj odrazili su se prije svega financijski problemi. Ne samo da je manjkalo novca za preuređenje starih te izgradnju novih stambenih objekata već i za rušenje „divlje gradnje“, većinom sagrađene na južnijim dijelovima grada, koja je nastala zbog manjka stambenog prostora te ostala jednim od problema u čitavom razdoblju urbanizacije grada. Stambena se izgradnja stoga odvijala jako sporo; čak se unutar deset godina situacija nije poboljšala, niti je pokrivala $20 \%$ onoga što je bilo potrebno izgraditi za sve veći broj stanovništva. ${ }^{3}$ Jednim je dijelom poslijeratnom Zagrebu dobro došla uspješna stambena izgradnja grada u razdoblju između dvaju ratova, odnosno do 1940. godine, $s$ time da je i tada, a onda i kasnije, ostalo problematično pitanje velikog broja prizemnica, na koje se rasipala zemljišna površina. Osim toga, glavni je problem ostajao porast „divlje gradnje“ bez građevinske dozvole. Situacija se tek postupno mijenja jer više nisu privatnici ti koji grade stambene objekte, već država, gradske općine i njihove institucije ili poduzeća. ${ }^{4}$ Ipak, stanje se do 1955 . godine nije poboljšalo, čak naprotiv, može se reći da je problem postao ozbiljniji. Razloga je bilo nekoliko: nagli porast gradskog stanovništva, broja domaćinstava, zatim spora i oskudna stambena izgradnja, a razlika između ovih čimbenika bila je s godinama sve veća. Intenzitet stambene izgradnje bio je među najslabijima u Europi. Problem i dalje ostaje velik broj prizemnica i jednokatnica umjesto planske izgradnje viših zgrada i nebodera, kako bi se u njih moglo smjestiti veći broj ljudi. ${ }^{5}$

Naglo širenje gradskog područja na okolne općine dalo je poticaj za stvaranje plana za izgradnju poslijeratnog Zagreba. Godine 1945. gradu je pripojena Kustošija, Bukovački Breg I., zatim 1949. Bukovački Breg II., jugozapadni dio Granešine, Zagrebačka Dubrava i Čulinečka Dubrava I. Najveća teritorijalna promjena dogodila se 1950., kada su pripojene općine: Stenjevec, Vrapče, Šestine, Gračani, Remete, Markuševac, Resnički gaj i Savski gaj, te 1952. godine: Resnička Trnava, Čulinečka Dubrava II., Resnički gaj i manji dio Podsusedskog Jarka. ${ }^{6}$

Gradske vlasti okreću se dodatnom razvijanju dvaju glavnih čimbenika Zagreba - industrijalizaciji i urbanizaciji grada. Za Zagreb bilo je ključno obnoviti, razvijati i poticati industrijski razvoj kao jedan od glavnih industrijskih središta u državi. Zastarjela i manjeviše neprikladna industrijska postrojenja trebalo je izbaciti iz užeg centra grada, kako bi se mogla slobodno širiti te kako bi se umanjilo zagađenje. Stoga se planiralo osnivanje četiriju industrijskih zona: Žitnjaka za nečiste industrijske pogone, a u ostalim trima zonama (Jakuševac, Jankomir te Hrvatski Leskovac) razvijala se čista industrija. Unatoč naporima, neke industrije ipak ostaju u užem dijelu grada. ${ }^{7}$

Industrijalizacija je uključivala izgradnju novih tvornica - Tvornice parnih kotlova i hidrauličkih strojeva na Žitnjaku te kombinat „Jedinstvo“, kao i rekonstrukciju i proširenje starih postrojenja, poput tvornice „Rade Končar“. Tvornica parnih kotlova, elektroindu-

3 Povijest grada Zagreba, knj. 2: 20. i 21. stoljeće, Zagreb 2013., 178; T. Tiмeт, Stambena izgradnja Zagreba do 1954. godine. Ekonomsko-historijska analiza, Zagreb 1961., 189.

4 T. Tiмeт, „Prilog poznavanju stambene izgradnje Zagreba“, 274.

5 Isti, Stambena izgradnja Zagreba, 189, 200, 202.

6 Isti, „Prilog poznavanju stambene izgradnje Zagreba“, 274-275.

7 Zdenko KolaCio, „Problemi urbanističkog razvoja Zagreba“, Iz starog i novog Zagreba, sv. 3, 287-288. 
strija „Tesla“, farmaceutska tvornica „Pliva“ te spomenuti „Rade Končar“ u pedesetima doživljavaju procvat. Velik dio tvornica selio se na Žitnjak - INA i OKI kao najveća postrojenja te neki od pogona tvornice „Rade Končar“. Radilo se i na obnovi i proširenju gradske infrastrukture, ponajprije opskrbom grada strujom, izgradnjom Elektrane 1947. godine, zatim plinom u razdoblju do 1958. godine. Ipak, najveći pomak napravljen je izgradnjom Termoelektrane, odnosno toplane 1963. godine, čime je Zagreb posjedovao prvi takav sustav grijanja u Jugoslaviji. Velik doprinos u razvoju industrije i znanosti imao je Institut „Ruđer Bošković", osnovan 1952. godine, koji je postao vodećim hrvatskim institutom za područje atomske fizike. Sâm Većeslav Holjevac za vrijeme svog mandata u više ga je navrata posjećivao te razgledavao radove i preuređenja u Institutu. ${ }^{8}$

Urbanizacija je tekla teže i sporije; povjesničar Tomislav Timet u svojoj knjizi urbanizaciju dijeli na dvije faze: prvu od 1946. do 1954. te drugu do 1962., s time da je za vrijeme druge napravljen znatan pomak u broju stanova. ${ }^{9}$ Gradnja je sve življa do 1962. godine, stanovi su sada već dvosobni ili jednosobni te je u dvije godine (1960 - 1962.) postignut uspjeh kakav nije postignut ni u međuratnom razdoblju. Ključan je pritom problem bila činjenica da „Generalni regulacioni plan grada Zagreba“ iz 1937. godine zbog rata i poslijeratnih organizacijskih promjena nije proveden (jedino je Cvjetno naselje velikim dijelom uspješno realizirano) te je ukinut 1945. U poslijeratnom razdoblju krenulo se s izradom urbanističkog plana, koji se prvotno nije odvijao prema planu jer je najprije trebalo obnoviti velik broj ratom uništenih zgrada pa je novi plan „Direktivna regulativna osnova“ dovršen tek 1953., a zbog neslaganja nije ni prošao. Ponajprije se išlo za rješavanjem cestovnih problema, pitanja željeznice i prometne povezanosti, a zatim se planirala izgradnja zgrada s četirima do osam katova u novom centralnom dijelu Trnja - jugozapadnom Zagrebu. ${ }^{10}$ Ipak, željelo se izbjeći skupe zahvate pa se u prvim planovima preskače plansku izgradnju Trnja i Trešnjevke zbog, između ostalog, problema nastalih uslijed „divlje gradnje“, stoga su ti dijelovi bili puno lošije izgrađeni nego pomno isplanirana gradnja Novog Zagreba. Ti novi dijelovi grada morali su biti zaokružene cjeline, imati škole, vrtiće, trgove, centre, rekreativne površine te biti dobro prometno povezani, ali su neki objekti, poput bolnica, ostali zanemareni u prvim godinama urbanog planiranja. ${ }^{11}$

Za sve je ovo velikim dijelom bio zaslužan Većeslav Holjevac, zagrebački gradonačelnik - točnije, predsjednik Gradskog narodnog odbora Zagreb od 1952. do 1963. godine. Zanimljivo je da je gradonačelniku, unatoč tome što je u nekoliko svojih mandata i punih jedanaest godina na poziciji napravio mnogo za industrijalizaciju i urbanizaciju grada,

$8 \quad$ Povijest grada Zagreba, sv. 2, 182, 185, 188, 192-193, 210.

9 T. Timet, „Prilog poznavanju stambene izgradnje Zagreba“, 274, 277.

10 Vedran Ivanković, „Arhitekt Vladimir Antolić - zagrebački urbanistički opus između dva svjetska rata“, Prostor, 17/2009., br. 2 (38), 269-283; Z. Kolacio, „Problemi urbanističkog razvoja Zagreba“, 281-284; Povijest grada Zagreba, sv. 2, 177.

11 Z. Kolacio, „Problemi urbanističkog razvoja Zagreba“, 299; Povijest grada Zagreba, sv. 2, 178.

12 O tome v. Većeslav Holjevac: graditelj, vizionar, ratnik (ur. Juraj Hrženjak), Zagreb 2007.; Josip Minaljević, „Većeslav Holjevac - Forgotten Dissident“, Prispevki za novejso zgodovino, 58/2018., br. 3, 128-147; Isti, „Stota obljetnica rođenja Većeslava Holjevca (1917.-1970.)“, Zagreb moj grad, 11/2017., br. 64, 6-11; Iva KraLjević-BAšić, „Matica iseljenika Hrvatske 1964.-1968.“, Časopis za suvremenu povijest, 41/2009., br. 1, 71-92; Katarina SPEHnjaK, „Većeslav Holjevac u političkim zbivanjima u Hrvatskoj 1967. godine“, Časopis za suvremenu povijest, 32/2000., br. 3, 567-593. 
posvećeno uglavnom malo historiografskih radova. ${ }^{12}$ Veći naglasak stavljalo se na njegovo razdoblje provedeno u partizanima ili kasnije pri radu Matice hrvatske, a jednim je dijelom bio „zaboravljen“ zbog neslaganja s državnim vlastima za vrijeme objavljivanja „Deklaracije o nazivu i položaju hrvatskog književnog jezika “. 13

Među Holjevčevim prvim bitnim projektima bili su izgradnja Mosta slobode - kao poveznica Starog i Novog Zagreba - te masovna stambena izgradnja uzduž Ulice proleterskih brigada. Izgradnja Trnja, točnije, Sveučilišne aleje, planirane još od kraja pedesetih, jedan je od nerealiziranih projekata pa se nije ostvarila ni ideja da Trnje postane stvarnim sveučilišnim središtem, unatoč tome što je izgrađeno Pučko učilište „Moša Pijade“, zgrada Elektrotehničkog (ETF) te Filozofskog fakulteta. ${ }^{14}$

Početkom 1950-ih dolazi do prvog prijelaza preko Save izgradnjom zgrada u Savskom gaju. Započinje izgradnja „Velesajma“ koji se, nakon dugogodišnjeg boravka na prostoru današnjeg Studentskog centra te kasnijeg proširenja na današnji Tehnički muzej, konačno zbog manjka prostora preselio u novu zgradu u Novom Zagrebu preko južne obale Save, gdje je svečano otvoren 1956. godine. ${ }^{15}$ Taj nezaboravni događaj obilježila je i Televizija Zagreb svojim prvim emitiranjem uživo s otvorenja. „Velesajam“ postaje ključnim državnim i međunarodnim trgovačkim središtem te su njegovi proljetni i jesenski sajmovi bili dobro posjećeni, a broj izlagača, paviljona i posjetitelja bio je iz godine u godinu sve veći. Sâm je Tito često dolazio na sajam; otvorenje prvog jesenskog sajma prilikom prelaska u novu zgradu preko Save upravo je uprizoreno uz njegovu prisutnost.

Izgradnja Novog Zagreba trebala je riješiti problem imigracije proizašle iz deagrarizacije i industrijalizacije. Južni potez između Save i pruge - Trnje - prema arhitektu Vladimiru Antoliću, trebao je biti novi centar grada s Moskovskom avenijom (danas Vukovarska ulica) kao glavnom prometnicom $s$ novim objektima gradske vlasti, kulturnih i obrazovnih institucija te stambenim objektima. ${ }^{16}$ To se mijenja izgradnjom „Velesajma“ preko Save, kojim je uvedena i infrastruktura (električna, plinska, vodna, prometna) te se izvode produženja dotadašnjih ulica. Treba naglasiti kako je izgradnja Mosta slobode bila ključna za urbanizaciju prostora preko Save. ${ }^{17}$ Najprije se izgrađuje Savski gaj 1957. te Remetinečki gaj. Trnsko se gradi 1959. godine kao prvo cjelovito planirano naselje. U drugoj fazi 1963. - 1968. gradi se Zaprude, a zatim slijede Sopot i Utrine, prema istom planskom programu, te Siget. Probleme su stvarala razna naselja niske stambene gradnje, nastala zbog „divlje gradnje“, poput Kajzerice. ${ }^{18}$ Takvi su dijelovi grada imali velikih problema s higijenom te opskrbom vodom i strujom.

\footnotetext{
13 K. SpehnjaK, „Većeslav Holjevac u političkim zbivanjima u Hrvatskoj 1967. godine“, 567-593.

14 Povijest grada Zagreba, sv. 2, 180-181.

15 Isto, 182.

16 V. Ivanković, „Arhitekt Vladimir Antolić“, 269-283.

17 T. Timet, „Prilog poznavanju stambene izgradnje Zagreba“, 277; Valentina Gulin Zrnić, Kvartovska spika. Značenje grada i urbani lokalizmi u Novom Zagrebu, Zagreb 2009., 41-44.

18 V. Gulin ZRnić, Kvartovska spika, 44-45.
} 


\section{Razvoj Radiotelevizije Zagreb}

Radiotelevizija Zagreb svoj put započinje prvim eksperimentalnim programom, koji se u početku temeljio na talijanskim i austrijskim sadržajima zbog nepostojanja domaćeg programa. Emitiranjem uživo sa „Zagrebačkog velesajma" te zatim prvim potpuno samostalnim eksperimentalnim programom iste godine nastaje prvi televizijski studij u Jugoslaviji. Ipak, put do uspona bio je težak, kompliciran te često usporavan političkim i društvenim problemima. Pri izradi ovog poglavlja u metodološkom smislu prije svega može poslužiti knjiga Ase Briggsa i Petera Burkea Povijest medija. ${ }^{19}$ U Europi se pitanje osnivanja televizijskog programa postavilo već u međuratnom razdoblju pa tako neke poznatije radijske kuće, poput BBC-ja, kreću eksperimentirati već u 1920-ima. Unatoč uspješnim emitiranjima i popularizaciji televizijskog programa, televizija svoj procvat doživljava tek u 1950-ima. ${ }^{20}$ U Jugoslaviji, ponajprije u Zagrebu, o osnivanju televizije govorilo se već na Komitetu za radiofuzne službe Vlade FNRJ na kojem je kao glavna smjernica izrađen „Nacrt perspektivnog plana radiofikacije FNRJ“za razdoblje između 1955. i 1960. godine. ${ }^{21}$ To se pitanje postavilo jer je već određen broj kućanstava posjedovao televizijske uređaje na kojima su hvatali strane talijanske i austrijske programe. Ipak, smatralo se da se pitanje osnivanja televizije ne bi trebalo povlačiti na državnoj razini sve dok se ne izgradi čvrsta državna radijska veza, provođenjem sve jače centralizacije te dok se ne stvore uvjeti za izradu zajedničkog televizijskog programa Zagreb - Beograd - Ljubljana. ${ }^{22}$ Također, nije se moglo govoriti o osnivanju televizije dok je radio imao raznih razvojno-tehničkih problema, poput pomanjkanja opreme, lošeg signala, uske radioveze itd.

No, u Zagrebu se počinje razmišljati o osnivanju televizije. Kada su vijesti došle do ostalih republika, koje nisu bile spremne za takav pothvat, ubrzano se kreće u neku vrstu nadmetanja tko će biti prvi u stvaranju televizijskog programa u Jugoslaviji. U Zagrebu se počinje eksperimentirati signalom te skupina tehničara na Sljemenu uspijeva uspostaviti signal, a na ekranu pojavljuje se „snijeg“. Odlučeno je da će se prvi televizijski program emitirati na obljetnicu trideset godina Radio Zagreba te se počinje intenzivnije raditi na provedbi plana. Ubrzo se poteže pitanje nabave opreme, što nije bilo moguće napraviti unutar države zbog međusobnog neslaganja te se traži strane investitore u Italiji, Austriji i Francuskoj, što je izazivalo određene kontroverze, s obzirom na to da se radilo o suradnji s kapitalističkim zapadnim zemljama. Ipak, prva oprema nabavljena je od francuskog CFTH-a, a prve emisije za emitiranje bile su dogovorene $s$ austrijskim i talijanskim televizijama. ${ }^{23}$

Prvo osoblje koje je radilo na osposobljavanju televizije bili su većinom ljudi s Radio Zagreba. Zlatko Sinobad je, zajedno s tadašnjim generalnim direktorom Radija, Ivanom Šiblom, bio među prvima koji su pokrenuli ideju o televiziji. Prvo televizijsko osoblje došlo

\footnotetext{
19 A. Briggs i P. Burke, Socijalna povijest medija.

20 Isto, 205-208, 248.

21 Nikola Vončina, TV osvaja Hrvatsku. Prilozi za povijest radija i televizije u Hrvatskoj III (1954. - 1958.), Zagreb 1999., 86.

22 Isto, 113-114.

23 Isto, 132-135.
} 
je s Radija, među njima i glavni inženjer Roman Galić, uz kojeg su se našla mnoga druga poznata imena - Vojko Trs kao tehnički direktor, Mario Fanelli kao režiser, Marija Ritz, Ivo Vuljević, Ivan Sušanj, Zdenka Pranjić itd. Dakle, osoblje koje je bilo potrebno za rad s kamerama, filmovima ili je bilo dovedeno iz filmskih kuća poput „Jadran filma“, ili su se održavali tečajevi za obuku mladih ljudi. U ovakvom sastavu prvu skupinu činilo je oko 20 osoba. $^{24}$

Prvi prijam sa Sljemena dogodio se 15. svibnja 1956., a samo radi te prigode kupljeni su i postavljeni televizori u izloge na zagrebačkim trgovima, oko kojih su se s iščekivanjem okupljali ljudi. Nakon prikazane rešetke pojavio se austrijski program, koji se na televiziji prikazivao neko vrijeme zbog nedostatka domaćeg programa. Ubrzo je potom iz Beograda stigla opomena i zahtjev o obustavi programa jer se smatralo da program koji su prenosili nije bio prikladan zato što je dolazio iz drugačije ustrojene, kapitalističke zemlje. Povjesničar i kroničar televizije Nikola Vončina u svojoj knjizi navodi kako je tada bitnu ulogu u očuvanju televizije odigrao upravo Vladimir Bakarić, dokazujući se tako ne samo na republičkoj već i na državnoj razini. ${ }^{25}$

Prvi eksperimentalni domaći program sastojao se od kratkih vijesti te nekoliko kraćih zabavnih i glazbenih emisija snimljenih u studiju, a sve je to bila vježba za nadolazeće snimanje otvorenja „Velesajma“. $\mathrm{Na}$ „Velesajmu“ bio je montiran studio te se sve snimalo s pomoću dvije kamere; prvi kadar bila je snimka s krova „Velesajma“ koja je prenosila pogled na Sljeme te zatim na zgrade „Velesajma“. Mogu se vidjeti kadrovi ljudi koji iščekuju otvorenje, svečanu povorku na čijem su čelu bili Tito, Bakarić i Holjevac, a poseban trenutak koji se željelo uhvatiti bilo je rezanje vrpce koje je bilo povjereno Titu. ${ }^{26}$

Oformljivanjem ostalih republičkih televizijskih kuća tijekom 1958. godine polako se radilo na izradi zajedničkog programa, koji zbog prekida signala i drugih problema nije realiziran sve do sljedeće godine. I tada su se vijesti dugo emitirale iz Zagreba i Ljubljane u slučaju prekida signala s Beogradom; ponekad se nisu mogle emitirati svakodnevno, već tjedno (pa se u početku razmišljalo o nazivu emisije $T V$ tjednik umjesto $T V$ dnevnik) ili su ih zamjenjivale Filmske novosti s često zastarjelim informacijama. Postojanje zajedničkog programa postaje problem za domaći program zbog sve veće kontrole nad televizijom iz Beograda, a do postupne liberalizacije dolazi tek krajem 1970-ih. ${ }^{27}$ Program je u početku bio kratak, savezni $T V$ dnevnik trajao je oko pola sata na početku i na kraju emitiranja dnevnog programa. Tek formiranjem Zagrebačkog tjednika početkom šezdesetih godina, za što je osobno bio zaslužan Holjevac, a kasnije i emisije Jučer, danas, sutra, koja dobiva značajke hrvatskog $T V$ dnevnika, od 1963. godine polako dolazi do osamostaljivanja domaćeg Informativno-političkog programa Studija Zagreb. U vremenu nakon zagrebačke poplave 1964. godine, počinje se jasnije vidjeti napredak RTZ-a, što se manifestira u sve bogatijem programu (dnevnik, vijesti, televizijske drame, filmovi, sportski pregledi, program za djecu

27 Isto, 291-316; Ista, RTV Zagreb 1959. - 1964. Prilozi za povijest radija i televizije u Hrvatskoj IV, Zagreb 2001., 221-224. 
i omladinu, poljoprivredne, propagandne i glazbene emisije, a kasnije, od 1965., Ekran na ekranu, glazbeno-zabavna emisija), duljem trajanju i sve boljoj pokrivenosti obavještajnog programa. ${ }^{28}$

\section{4. „Velesajam“ Na snimkama Televizije Zagreb}

Povezujući navedene aspekte, ponajprije bi se trebalo osvrnuti na „Zagrebački velesajam“ jer se na tom primjeru najbolje može uvidjeti međuodnos Televizije Zagreb, urbanog razvoja poslijeratnog Zagreba i gradonačelnika Holjevca. Svečano otvorenje sajma i snimka uživo odigrali su veliku ulogu u afirmiranju televizije, Holjevca u državnim krugovima te Zagreba kao jednog od glavnih državnih središta. To je posebno vidljivo iz mnogih kasnije snimljenih emisija ${ }^{29}$, u kojima se često pronalaze snimke otvorenja kadrovi zgrade „Velesajma“, uređenog prostora, različitih paviljona, ljudi koji nestrpljivo iščekuju otvorenje, a glavno mjesto zauzima kratak isječak Titova rezanja vrpce u društvu Holjevca i Bakarića. ${ }^{30}$

Pri analizi televizijskih isječaka Filmskih vijesti, Vijesti, TV dnevnika i Zagrebačkog tjednika ističu se „Velesajam“ te njegove jesenske i proljetne izložbe, koje i dalje zauzimaju bitno mjesto u dnevnim i tjednim izvještajima. Veliku se važnost pridaje posjetima raznih stranih državljana, koji u pratnji Tita, Holjevca i Bakarića razgledavaju paviljone te raspravljaju o najnovijim proizvodima. ${ }^{31}$ Suradnja s drugim europskim i svjetskim zemljama bila je izuzetno bitna ne samo za Zagreb već i za Jugoslaviju. U prvim je godinama naglasak bio na suradnji s velikim europskim trgovačkim zemljama - Čehoslovačkom, Istočnom i Zapadnom Njemačkom te svjetskim silama, Sjedinjenim Američkim Državama i Sovjetskim Savezom, koje među prvima dobivaju vlastite paviljone na „Velesajmu“. Snimaju se razni intervjui s prodavačima iz navedenih zemalja, kako bi se ukazalo na dobru suradnju tih zemalja s Jugoslavijom te pokazalo da je i ona važan sudionik međunarodne trgovine. U kasnijim godinama veći se naglasak stavlja na suradnju sa zemljama Trećeg svijeta pa se radi na izgradnji njihovih paviljona, kako bi se i oni mogli pokazati na svjetskom tržištu. ${ }^{32}$ Važnost suradnje sa zemljama Trećeg svijeta ističe i Tito u jednom intervjuu iz 1976. godine te smatra kako je bitno da se tako pomogne razvoju tih zemalja te da se usporedno šire i

28 Ista, RTV Zagreb 1959. - 1964., 221-224, 228.

29 Arhiv Hrvatske radiotelevizije (dalje: Arhiv HRT), Od zbora do Velesajma, IMX-33042 (datum emitiranja 15.11. 1999.); Arhiv HRT, Jubilej Zagrebačkog velesajma, 12379/211253 (datum emitiranja 1. 1. 1976.); Arhiv HRT, Grad, prostorna organizacija, IMX-33068; Arhiv HRT, Zagreb, industrijalizacija i rast, IMX-55158 (godina emitiranja 1984.).

30 Arhiv HRT, Od zbora do Velesajma, IMX-33042 (datum emitiranja 15. 11. 1999.); Arhiv HRT, Počeli smo prije dvadeset godina, IMX-53526 (datum emitiranja 10. 5. 1976.).

31 Arhiv HRT, Vijesti, 303/4252 (datum emitiranja 17. 4. 1963.); Arhiv HRT, Vijesti, 634/11858; Arhiv HRT, Filmske vijesti, 157/16311; Arhiv HRT, Filmske vijesti, 157/1639; Arhiv HRT, Filmske vijesti, 7/67; Arhiv HRT, Velesajam, T163/12351; Arhiv HRT, Tito na Zagrebačkom Velesajmu, 3/41; Arhiv HRT, Filmske vijesti, 157/1630; Arhiv HRT, Filmske vijesti, 7/65.

32 Arhiv HRT, Od zbora do Velesajma, IMX-33042 (datum emitiranja 15. 11. 1999.); Arhiv HRT, Filmske vijesti, Zagrebački velesajam, 196/1983. 
paviljoni i sâm „Velesajam“. Iz tog intervjua vidljivo je da Tito hvali „Velesajam“, ponajprije zato što se na jednome mjestu nalaze mnogi stručnjaci iz raznih svjetskih država te se tako zainteresirani posjetitelji mogu informirati o novitetima u industriji. Također naglašava da je daljnji razvoj „Velesajma“ nužan za privredu, zbog čega negativno gleda na izgradnju nebodera u okolici sajma, smatrajući da je potrebno omogućiti uvjete za slobodno širenje „Velesajma“, kako bi još dugo ostao među vodećima. ${ }^{33}$

Iz godine u godinu, na temelju snimki „Velesajma“, može se pratiti napredak televizije. Reportaže su sve duže i raznovrsnije, snimljeni su govori gradonačelnika Holjevca na otvorenjima ${ }^{34}$, a čak i poneki razgovor s Titom. Također, uspoređujući dvije kasnije snimljene emisije posvećene razvoju „Velesajma“, može se uočiti koliku je važnost imao za razvoj Zagreba u cijelom 20. stoljeću. Jedna od prvih takvih emisija jest Jubilej Zagrebačkog velesajma s kraja sedamdesetih godina, a druga Od zbora do Velesajma s kraja devedesetih. Obje emisije osvrću se na razvoj „Velesajma“ od njegovih početaka na prostoru današnjeg Studentskog centra, uspoređujući snimke starih s novim paviljonima. Ukazuje se na probleme koje je „Velesajam“ imao do preseljenja u nove prostore preko Save. Svrha obiju emisija bila je pokazati razvoj ponude sajma od otvorenja 1956. do sve raznovrsnijih eksponata u kasnijim godinama, od strojeva i tekstila do automobila. ${ }^{35}$ Dok je emisija iz devedesetih više napravljena kao kraći pregled, gdje se više prostora pridavalo i ranim počecima „Velesajma“", Jubileju Zagrebačkog velesajma veći je fokus na prelasku preko Save te uključuje ne samo već spomenuti intervju s Titom već i s nekolicinom stručnjaka koji su prisustvovali izgradnji novog „Velesajma“. ${ }^{37}$ To ne treba začuditi s obzirom na to da emisija nastaje 1976. u Jugoslaviji te se očito njome trebalo promovirati uspješnost socijalističkog razvoja jer i Tito zauzima veliku ulogu u snimkama emisije te se tvrdi kako je posjećivao sve jesenske izložbe, a ako ne bi mogao prisustvovati otvorenju, pobrinuo bi se da „Velesajam“ posjeti neki drugi dan. Emisija sadrži i velik broj raznih zahvala Titu zbog međunarodne afirmacije „Velesajma““38 U Jubileju se Holjevca samo letimično spominje, iako se pokazuje na gotovo svim snimkama. Ipak, navodi se kako je zaslužan za prijelaz „Velesajma“ preko Save te da je sudjelovao pri prvim planovima, što je prikazano i na snimkama, dok mu se u emisiji Od zbora do Velesajma pridaju veće zasluge..$^{39}$ Moglo bi se zaključiti kako Holjevac u razdoblju nakon Hrvatskog proljeća, pristajući uz „Deklaraciju o nazivu i položaju hrvatskog književnog jezika“, zbog čega je isključen iz političkog života, nije bio politički podoban pa ga se nije željelo isticati u sedamdesetima.

Važnost „Velesajma“ pokazuje se i u reportažama, čiji je fokus na raznovrsnoj ponudi „Velesajma“ i njegovih paviljona te na popularnosti izložbi koja je iz godine u godinu sve veća. Na snimkama možemo pratiti promjenu količine i raznovrsnost proizvoda. Jedna ta-

33 Arhiv HRT, Jubilej Zagrebačkog velesajma, 12379/211253 (datum emitiranja 1. 1. 1976.).

34 Ti govori većinom nisu sačuvani u arhivu ili je sačuvana samo vizualna, ali ne i audiosnimka.

35 Arhiv HRT, Jubilej Zagrebačkog velesajma, 12379/211253 (datum emitiranja 1. 1. 1976.); Arhiv HRT, Od zbora do Velesajma, IMX-33042 (datum emitiranja 15. 11. 1999.).

36 Arhiv HRT, Od zbora do Velesajma, IMX-33042 (datum emitiranja 15. 11. 1999.).

37 Arhiv HRT, Jubilej Zagrebačkog velesajma, $12379 / 211253$ (datum emitiranja 1. 1. 1976.).

38 Isto.

39 Isto. 
ko prikazuje građane koji promatraju ponudu sajma pa se izmjenjuju kadrovi raznih prehrambenih proizvoda, poput onih iz tvornice „Argo“, zatim kućanskih aparata i namještaja, gdje posjetitelji zapanjeno promatraju nove rasklopive ormare i ostale vrste pokućstva, do kadrova masovnih strojeva, poput traktora, buldožera te, naravno, najnovijih modela automobila. ${ }^{40}$

\section{Televizija o televiziji: OBljetničKe EMisije POVODOM OBILJEŽAVANJA OSNUTKA RadioteleVizije ZaGREB}

Za samu Televiziju Zagreb bilo je bitno zabilježiti vlastiti uspon i napredak koje je bilježila u svojim reportažama. Ostaju sačuvane mnoge emisije u povodu obilježavanja nastanka Radija i Televizije Zagreb, pa tako imamo uvid u snimke za desetu, dvadesetu, četrdesetu obljetnicu osnutka radija i televizije. ${ }^{41}$ Prve su snimke dosta loše snimljene, kadrovi su kratki, bez velike povezanosti te samo u kratkom vremenskom razmaku daju uvid u neke od događaja koje je RTZ smatrao bitnima, poput otvorenja „Velesajma“ i Titova rezanja vrpce, prvih kadrova studija, voditelja, opreme i slično. Povodom dvadesete obljetnice RTZ-a napravljena je specijalna emisija u kojoj su sudjelovali mnogi djelatnici televizije, zaslužni za njezine početke, a iz emisije vidljivo je da je prvo emitiranje uživo s „Velesajma“ imalo veliku težinu. ${ }^{42}$ Zlatko Sinobad prisjeća se kako su sve pažljivo planirali - postavili su improvizirani studio na „Velesajmu“, dvije posuđene kamere, a prva je slika bila snimljena i poslana s pomoću kamere na „Velesajmu“ zahvaljujući vezi sa Sljemenom, dok Fanelli spominje kako se prije toga sve uvježbavalo drvenim kamerama u studiju. Snimanje je prošlo uspješno unatoč kratkom kvaru na kameri točno prije rezanja vrpce, ali je uspješno otklonjen na vrijeme. Ova prva javna emisija trajala je 25 minuta, a promocija otvorenja „Velesajma“ te prijenos uživo pridonijeli su pozitivnoj reakciji državnog vrha na dotad ne tako popularnu ideju gradonačelnika Holjevca o izgradnji „Zagrebačkog velesajma“. ${ }^{43}$ Koliko je osnivanje Televizije Zagreb bilo bitno za gradonačelnika i popularizaciju njegova mandata, pokazuje televizijski intervju s Holjevcem u kojem se osvrnuo ne samo na nove urbane planove i gradnju već i na razvoj televizije te njezin doprinos sveukupnom urbanom razvoju. Između ostaloga, govorio je o planovima izgradnje i problemima Zagreba, posebno u stambenoj izgradnji. Iznio je i svoje mišljenje o televiziji, izrazivši zadovoljstvo što je Zagreb dobio tu novu ustanovu i čestitao na dotad postignutim uspjesima. ${ }^{44}$

\footnotetext{
40 Arhiv HRT, Filmske vijesti, 129/1046; Arhiv HRT, Filmske vijesti, 129/1047; Arhiv HRT, Filmske vijesti, 129/1048; Arhiv HRT, Filmske vijesti, 129/1049.

41 Arhiv HRT, Filmske vijesti, 136/1274; Arhiv HRT, Počeli smo prije dvadeset godina, IMX-53526 (datum emitiranja 10. 5. 1976.).

42 Arhiv HRT, Počeli smo prije dvadeset godina, IMX-53526 (datum emitiranja 10. 5. 1976.).

43 Isto.

44 N. Vončina, RTV Zagreb 1959. - 1964., 182-183.
} 


\section{Percepcija Većeslava Holjevca i njegovih POSTIGNUĆA U TELEVIZIJSKIM REPORTAŽAMA}

Reportaže urbanog širenja Zagreba isprepleću se s onima koje prikazuju gradonačelnika Holjevca, pridajući važnost prijenosima svečanih otvorenja („Velesajam“, tvornice, izložbe, škole itd.) te njegovim govorima pri bitnim urbanim pomacima. Govori su se najčešće održavali pred većom skupinom ljudi, pred političarima u Skupštini, kojima bi se Holjevac obraćao s podija, govoreći u mikrofon, kako bi ga se u svim dijelovima sobe moglo dobro čuti. Pokoji sačuvan govor prikazuje Holjevca u jednostavnijem okruženju, poput gradilišta na „Velesajmu“, ili u dijelovima Novog Zagreba kako se, najčešće u društvu Bakarića, obraća slušateljima. Holjevca se nazivalo i nastojalo prikazati narodnim čovjekom, osobom koja se raduje i aktivno prisustvuje u svakoj radnoj akciji, koja hoda po gradilištima te pomno prati tijek izgradnje. On se, kao i nakon njega Pero Pirker, pojavljuje često u novinama i na televiziji. Nije mu smetalo davanje intervjua i razgovori o aktualnim ili raznim drugim događanjima i planovima za vrijeme njegova mandata, što je moguće vidjeti i iz izjave u jednom intervjuu iz 1962. U Zagrebačkoj panorami, na kraju svog petogodišnjeg mandata, najbolje je vlastitim riječima opisao ciljeve i uspjehe uprave: ustvrdio je kako dvama najvećim postignućima uprave smatra: razvoj industrije, posebno izgradnjom Organsko-kemijske industrije (OKI), te planski prijelaz Zagreba preko Save. ${ }^{45}$ Razlog zbog kojeg je mogao pokrenuti i provesti planove bila je povoljnija ekonomska situacija i liberalizacija u državi koja mu je omogućila veću slobodu na lokalnoj razini. ${ }^{46}$

Među prvim planovima zabilježen je proces gradnje Mosta slobode, od prikaza prvobitnih planova, snimki izgradnje nasipa i stupova, kadrova Holjevca pri postavljanju kamena temeljaca do prvih automobila, koji su se uspješno prevezli na drugu stranu mosta u trenutku svečanog otvorenja. ${ }^{47}$ Razvoj grada zabilježen je $s$ dvaju aspekata - industrijskog i stambenog, s time da je veći naglasak bio na prvom jer je i sâm Holjevac smatrao da je za brži rast grada najvažniji industrijski razvoj. Stoga velik dio Filmskih vijesti, Vijesti, Zagrebačkog tjednika i emisije Jučer, danas, sutra zauzimaju snimke napretka u tvornicama, izgradnji novih i nadogradnji starih tvornica, pri čemu prisustvuje i gradonačelnik, poput posjeta tvornicama „Rade Končar“, „Fototeka“, „Tesla“ ili otvorenja Laboratorija za atomsko-biološku kemijsku zaštitu. Pri posjetu tvornici „Rade Končar“, Holjevac u pratnji vodstva tvornice obilazi pogone, a kasnije pred skupinom ljudi drži govor (audiosnimka nije sačuvana). Zabilježeni su i projekti izgradnje plinare, termoelektrane te automatske telefonske centrale, na čijim je otvaranjima ponovno Holjevac bio neizostavan faktor. ${ }^{48}$

Poteškoće pri analizi prezentacije urbanog razvoja Novog Zagreba proizlaze iz činjenice da, osim već spomenutog intervjua s gradonačelnikom Holjevcem, nije ostao sačuvan veći

45 Ivo Graovac, „Fenomen Veco Holjevac“, u: Većeslav Holjevac, 12.

46 „Većeslav Holjevac“, Hrvatska enciklopedija (http://www.enciklopedija.hr/natuknica.aspx?id=25994)

47 Arhiv HRT, TV kalendar, B-193873.

48 Arhiv HRT, Vijesti, 303/4252 (datum emitiranja 17. 4. 1963.); Arhiv HRT, Filmske vijesti, 136/1259; Arhiv HRT, Jučer, danas, sutra, IMX-55468 (datum emitiranja 30. 9. 1964.); Arhiv HRT, Filmske vijesti, IMX-94604; Arhiv HRT, Zagrebački tjednik, IMX-63004; Arhiv HRT, Zagrebački tjednik, 231/2865 (datum emitiranja 15. 11. 1962.); Arhiv HRT, Zagrebački tjednik, 246/3174 (datum emitiranja 29. 11. 1962.). 
broj reportaža o tom pitanju. U Jubileju spominju se početni planovi izgradnje iz 1950-ih godina na poljima južnog Zagreba, gdje je postavljena ploča s planom izgradnje, čijem je predstavljanju, uz gradonačelnika Holjevca, prisustvovao i arhitekt Marijan Haberle. ${ }^{49} \mathrm{Iz}$ kraćih reportaža u dužem vremenskom periodu može se dobiti bolji dojam te uvidjeti koliko je to bio zahtjevan i dugoročan proces. Tek u kasnijim godinama, kada se i televizija bolje razvija pa postoje mogućnosti za bolje dokumentiranje, ponajprije snimkama iz zraka, radi se na osvješćivanju gledatelja o urbanom razvoju i procvatu grada, ali se također upozorava na mnoge probleme, poput onečišćenja, napučenosti te neuravnoteženosti grada $\mathrm{i}$ periferije, do kojih dolazi zbog ubrzanog urbanog rasta. ${ }^{50}$ Od početnih crno-bijelih kadrova izgradnje prvih zgrada u Novom Zagrebu, gdje se pod skelama, betonom i zemljom naziru oblici budućih nebodera, izgradnje zgrada u pojedinim ulicama, uređenja škola, vrtića, parkova te kasnije i robne kuće „NAMA“ u Novom Zagrebu do snimki u boji završenih projekata može se pratiti usporedni rast Novog Zagreba i Televizije Zagreb. ${ }^{51}$

Holjevac se volio pojavljivati i na mnogim drugim bitnim političkim, sportskim i kulturnim događanjima te je često održavao svečana primanja raznih delegacija ili sportaša u svom uredu - poput nogometaša „Bayern Münchena“ te omiljenih nogometaša „Dinama“. ${ }^{2}$ Općenito se može steći dojam kako se pojavom televizije ovaj novi medij počinje koristiti za bolju i bržu reklamu gradske i državne vlasti. To je, naravno, bilo moguće jer je sve veći broj kućanstava posjedovao televizore, a slika je uz pažljivu montažu kadrova mogla prenijeti jasniju poruku. Za razliku od novina, koje su mogle ponuditi samo uvid u tekstualni prikaz nekog događaja, televizija donosi i prostorni i zvučni prikaz pa se ljudima sve činilo življim i kao da se stvarno nalaze na mjestu događaja. Stoga dolazi do suodnosa vlasti, televizije i građana jer se pojavom Holjevca u društvu Bakarića te Tita (pri najbitnijim događajima, poput otvorenja „Velesajma“) građanima prenosila poruka o suradnji gradskog i državnog vrha te ih se ujedno povezivalo sa svim važnim dostignućima urbanističkog razvoja Zagreba. Tako je moguće primijetiti Holjevca, Bakarića i Tita u šetnji „Velesajmom“, u pratnji raznih drugih stranih političara i vođa, te u razgledavanju prostora i izložaka. Također su česti kadrovi kolona ljudi koje s nestrpljenjem čekaju dolazak automobila, iz kojeg ih, pri izlasku, srdačno pozdravljaju Holjevac i Tito, a nerijetko se na snimkama može vidjeti Holjevca i Tita kako zajedno sjede i voze se u otvorenom automobilu dok mnoštvo maše zastavicama. Iz sličnih se razloga te kako bi se pokazalo koliku je važnost imao Holjevac ne samo za Zagreb već i za televiziju, na programu Televizije Zagreb dostojno obilježila njegova smrt (Holjevac umire 1970. godine te ga na poziciji zagrebač-

49 Arhiv HRT, Jubilej Zagrebačkog velesajma, 12379/211253 (datum emitiranja 1. 1. 1976.).

50 Arhiv HRT, Grad, prostorna organizacija, IMX-33068; Arhiv HRT, Jučer, danas, sutra, IMX-59026 (datum emitiranja 8. 7. 1965.); Arhiv HRT, Zagreb, industrijalizacija i rast, IMX-55158 (godina emitiranja 1984.).

51 Arhiv HRT, Grad, prostorna organizacija, IMX-33068; Arhiv HRT, Jučer, danas, sutra, IMX-59026 (datum emitiranja 8. 7. 1965.); Arhiv HRT, Zagrebački tjednik, IMX-94118; Arhiv HRT, Zagrebački tjednik, 231/2866 (datum emitiranja 15. 11. 1962.); Arhiv HRT, Zagreb, industrijalizacija i rast, IMX-55158 (godina emitiranja 1984.).

52 Arhiv HRT, Filmske vijesti, 129/1060 (datum emitiranja 13. 4. 1961.); Arhiv HRT, Filmske vijesti, 129/1063; Arhiv HRT, Filmske vijesti, 136/1270 (datum emitiranja 3. 5. 1961.); Arhiv HRT, Filmske vijesti, 196/1988; Arhiv HRT, Vijesti, 247/3211; Arhiv HRT, Zagrebački tjednik, IMX-63004; Arhiv HRT, Filmske vijesti, 157/1639; Arhiv HRT, Filmske vijesti, 132/1129; Arhiv HRT, Zagrebački tjednik, 229/2814 (datum emitiranja 8. 11. 1962.); Arhiv HRT, Zagrebackki tjednik, 231/2865 (datum emitiranja 15. 11. 1962.). 
koga gradonačelnika zamjenjuje Pero Pirker (1963. - 1967.)), popraćena komemoracijom u Vijećnici i sahranom, na kojoj je govorio budući zagrebački gradonačelnik Pero Pirker. On je u svom govoru naglasio ne samo brojne Holjevčeve zasluge i uspjehe za vrijeme Drugog svjetskog rata i sva priznanja koja je za to dobio već se osvrnuo i na njegovu važnost za sâm grad Zagreb te ostavštinu koju je ostavio budućim naraštajima za uspješnije daljnje urbanističko razvijanje grada. ${ }^{53}$

\section{Poplava 1964.}

Trenutak koji je pokazao nesavršenost zagrebačkog urbanog plana, ali i razvijenost Televizije Zagreb, bila je već spomenuta poplava. Dogodila se 24. listopada i trajala je do 27. listopada 1964. te je odnijela sedamnaest života. ${ }^{54}$ Voda je dosegnula visinu od $514 \mathrm{~cm}$ iznad normalnog - nabujala je iznad svih procjena i zahvatila grad, ulice, stanove. Televizija se tada pokazala doraslom situaciji i spremnom za rad na terenu jer su reportaže detaljno zabilježile ogromne površine vodom zahvaćenih područja, snimljenih ne samo snimkama u vožnji ili noću već i iz zraka, u trajanju i po nekoliko sati materijala, a obuhvaćena su sva područja od Jankomira do Trnja. Snimaju se prilozi o prihvatilištima, skloništima s javnom kuhinjom, problemima obitelji koje su ostale bez kuća, ali se ujedno koristilo i prilikom za promicanje socijalističkog planiranja i industrijskog rasta, poput reklamiranja tvornice montažnih kuća. ${ }^{55}$

Plan za borbu protiv elementarnih nepogoda bio je izuzetno manjkav te je uz to još nastao problem zbog velike količine oborina na gornjem dijelu Save, kao i loše regulacije tokova rijeka Krke, Sutle i Krapine, što je prouzročilo stvaranje jako velikog i brzog vodenog vala. Pero Pirker, tadašnji gradonačelnik, izjavio je kako je šteta ogromna. Za procjenu visine štete bila je organizirana Komisija za procjenu štete. Posao Komisije, zbog stalnog pronalaženja novih problema i troškova, nije bio nimalo lak. Šteta je na kraju procijenjena na 100 milijardi dinara, trećina je Zagreba stradala - dio Općine Črnomerec, više od polovine Trešnjevke do Trnja, Peščenice te dio Remetinca i dijelovi gotovo svih vanjskih općina. ${ }^{56}$ Ova poplava bila je prekretnica za razmišljanje o planu za smanjenje buduće moguće štete od poplava i za obuzdavanje Save. Planiralo se i projektiralo nove planove, rekonstruiralo postojeće nasipe te su se osigurala dodatna sredstva za početak izgradnje protupoplavnog sustava. ${ }^{57}$ Situacija nastala oko poplave Save, slično kao i prilikom drugih elementarnih nepogoda, poput ranijeg

53 Arhiv HRT, TV dnevnik, 2598/40169; Arhiv HRT, TV dnevnik, 2598/40170; Arhiv HRT, TV dnevnik, 2598/40173 (datum emitiranja 13. 7. 1970.).

54 Željko Kuzmić, Poplava u Zagrebu 1964. godine, Zagreb 2004., 6. Također o tome v. Mirela Slukan Altić, „Povijest regulacije rijeke Save kod Zagreba i njene posljedice na izgradnju grada“, Hrvatske vode, 18/2010., br. 73, 205-212; Drago RoKsandić, „Filozofski fakultet u poplavi 1964. godine: sjećanja i dokumenti“, Hrvatske vode, 18/2010., br. 73, 241-248.

55 Arhiv HRT, Jučer, danas, sutra, Poplava 1964., 1. i 2. dio, IMX-54388, IMX-55462; Arhiv HRT, Utrka svremenom, IMX-48430.

56 Ž. Kuzmić, Poplava u Zagrebu, 6-8.

57 Isto, 21. 
razornog potresa u Skoplju (1963.), dodatno je ukazivala na televiziju kao snažan medij informiranja i prevencije jer su snimke poplave predstavljale najizravniji način upozorenja. $\mathrm{Na}$ gore spomenute probleme osvrnula se televizija u prilogu Sava obuzdane ćudi, snimljenom 1984. godine. Intervjuiralo se razne stručnjake i upravitelje te se željelo razjasniti i ukazati na probleme tadašnjeg plana za obranu od poplava, zbog čega je došlo do brzog vodenog vala. Prilog je najvjerojatnije napravljen radi promocije novih planova za obranu od poplave te se to postiže ovakvom kombinacijom razgovora o situaciji prije i poslije poplave, kao i snimkama poplavljenog Zagreba i naselja te nasipa nakon obnove. ${ }^{58}$

\section{ZAKLJUČAK}

Analizirani aspekti usporednog razvoja urbane gradnje i Televizije Zagreb vidno su isprepleteni i kreću se proporcionalno. Za oboje je bitna poveznica bila sâm gradonačelnik Većeslav Holjevac, koji je svojom energičnošću i nastupima postao i simbol uspješno realiziranih projekata. Unatoč malobrojnim reportažama gradonačelnika i izgradnje grada, vidljivo je da je televizija odigrala veliku ulogu u reklamiranju ne samo „Velesajma“ već i industrijskog, urbanog te stambenog širenja Zagreba. Ujedno je ukomponirana i promidžba državne vlasti, Tita te socijalističkog načina upravljanja. Prateći razvoj i sve bolju kvalitetu televizijskih snimki, moguće je uvidjeti koliko se Televizija Zagreb razvila u prvih dvadeset godina postojanja te kako su političke i društvene prilike utjecale na njezin rast. Prve su snimke u crno-bijeloj tehnici te ne traju duže od nekoliko minuta (a pri samom otvorenju „Velesajma“ 1956. jedna od kamera kraće vrijeme nije funkcionirala). Kasnije emisije, poput Zagrebačkog tjednika ili Jučer, danas, sutra, iako su i dalje u crno-bijeloj tehnici sve do kraja 1970-ih, ipak čine zaokruženu cjelinu, dajući uvid u najvažnije događaje. Kadrovi „Velesajma“ i Zagreba u boji došli su tek puno godina kasnije u dužim emisijama s tonskim komentatorom, intervjuima i zračnim snimkama: tada je televizija odigrala glavnu ulogu u promidžbi urbanizacije Zagreba i „dovođenju“ novog prostora preko televizijskih ekrana u kuće gledatelja. Osim reklame urbanističkog razvoja, gledateljima je tako omogućen vizualni „dodir“ $s$ novim prostorom, premošćujući jaz između mogućih predodžbi i stvarnosti te, još važnije - pripremajući šire mase na novi izgled modernoga grada i moderne arhitekture. Postupno Zagreb u 1970-im i 1980-im godinama potresaju novi politički, industrijski i stambeni problemi. Oni se manifestiraju i posredstvom televizije, ponajprije u financijskim pitanjima, a potom u pitanju sve veće potrebe za novim studijem (kako je popularnost televizije rasla, javljalo se pitanje preseljenja u nove ili proširenja starih prostora redakcije zbog manjka prostora i opreme). Stoga bi bilo potrebno detaljnije istražiti i kasnije razdoblje radi boljeg razumijevanja i povijesti Zagreba i televizije.

\section{$\cos$}

$\overline{58}$ Arhiv HRT, Sava obuzdane ćudi, 22988/187180 (datum emitiranja 23. 10. 1984.). 


\section{Zagreb in the footage of The Zagreb Television I956 - I967: THE PROMOTION, REPRESENTATION AND URBANIZATION OF THE CITY}

Summary: After the Second World War, all aspects of life in Zagreb underwent a transformation, owing largely to the efforts of the city's mayor, Većeslav Holjevac. It is during his second term in office that Zagreb "crosses the Sava". The evolution of the Zagreb Radiotelevision (Radiotelevizija Zagreb, RTZ) occurs simultaneously with the city's development, since the television begins broadcasting experimentally in the 1950s, while the first live broadcast in the country's history takes place during the opening ceremony of the Zagreb Fair at its new location across the Sava. This paper examines the parallels between the origins of the Zagreb Television and the city's expansion, as documented by the television. Since Holjevac played a crucial role both in the urban planning project and the establishment of the television, an attempt is made to analyze the amount of airtime afforded to him, as well as the ways in which he used the new medium for self-promotion. The significance of the Zagreb Fair ever since its grand opening on the new location across the Sava in 1956 is also discussed, as it provides an opportunity to explore the correlations between the three major aspects of the paper. Additionally, the paper examines the television's perception of its own development, based on anniversary footage. As a matter of course, the representation of the expansion of Novi Zagreb is also analyzed, since it serves as a crucial reminder of how successful Holjevac was in his role as mayor.

Key words: Zagreb, Zagreb Radiotelevision (RTZ), urbanization, industrialization, Većeslav Holjevac, the Zagreb Fair, Novi Zagreb

\section{$\cos$}

\section{Izvori}

Arhiv Hrvatske radiotelevizije (Arhiv HRT)

Arhiv HRT, Filmske vijesti, 7/65.

Arhiv HRT, Filmske vijesti, 7/67.

Arhiv HRT, Filmske vijesti, 129/1046.

Arhiv HRT, Filmske vijesti, 129/1047.

Arhiv HRT, Filmske vijesti, 129/1048.

Arhiv HRT, Filmske vijesti, 129/1049.

Arhiv HRT, Filmske vijesti, 129/1060 (datum emitiranja 13. 4. 1961.).

Arhiv HRT, Filmske vijesti, 129/1063.

Arhiv HRT, Filmske vijesti, 132/1129.

Arhiv HRT, Filmske vijesti, 136/1259.

Arhiv HRT, Filmske vijesti, 136/1270 (datum emitiranja 3. 5. 1961.).

Arhiv HRT, Filmske vijesti, 136/1274.

Arhiv HRT, Filmske vijesti, 157/1630.

Arhiv HRT, Filmske vijesti, 157/1631.

Arhiv HRT, Filmske vijesti, 157/1639.

Arhiv HRT, Filmske vijesti, 196/1988. 
Arhiv HRT, Filmske vijesti, IMX-94604.

Arhiv HRT, Filmske vijesti, Zagrebački velesajam, 196/1983.

Arhiv HRT, Grad, prostorna organizacija, IMX-33068.

Arhiv HRT, Jubilej Zagrebačkog velesajma, 12379/211253 (datum emitiranja 1. 1. 1976.).

Arhiv HRT, Jučer, danas sutra, IMX-55468 (datum emitiranja 30. 9. 1964.).

Arhiv HRT, Jučer, danas sutra, IMX-59026 (datum emitiranja 8. 7. 1965.).

Arhiv HRT, Jučer, danas sutra, Poplava 1964., 1. i 2. dio, IMX-54388, IMX-55462.

Arhiv HRT, Od zbora do Velesajma, IMX-33042 (datum emitiranja 15. 11. 1999.).

Arhiv HRT, Počeli smo prije dvadeset godina, IMX-53526 (datum emitiranja 10. 5. 1976.).

Arhiv HRT, Sava obuzdane ćudi, 22988/187180 (datum emitiranja 23. 10. 1984.).

Arhiv HRT, Tito na Zagrebačkom Velesajmu, 3/41.

Arhiv HRT, TV dnevnik, 2598/40169.

Arhiv HRT, TV dnevnik, 2598/40170.

Arhiv HRT, TV dnevnik, 2598/40173 (datum emitiranja 13. 7. 1970.).

Arhiv HRT, TV kalendar, B-193873.

Arhiv HRT, Utrka s vremenom, IMX-48430.

Arhiv HRT, Velesajam, T163/12351.

Arhiv HRT, Vijesti, $247 / 3211$.

Arhiv HRT, Vijesti, 303/4252 (datum emitiranja 17. 4. 1963.).

Arhiv HRT, Vijesti, 634/11858.

Arhiv HRT, Zagreb, industrijalizacija $i$ rast, IMX-55158 (godina emitiranja 1984.).

Arhiv HRT, Zagrebački tjednik, 229/2814 (datum emitiranja 8. 11. 1962.).

Arhiv HRT, Zagrebački tjednik, 231/2865 (datum emitiranja 15. 11. 1962.).

Arhiv HRT, Zagrebački tjednik, 231/2866 (datum emitiranja 15. 11. 1962.).

Arhiv HRT, Zagrebački tjednik, 246/3174 (datum emitiranja 29. 11. 1962.).

Arhiv HRT, Zagrebački tjednik, IMX-63004.

Arhiv HRT, Zagrebački tjednik, IMX-94118.

\section{Literatura}

Asa Briggs, The BBC: The First Fifty Years, Oxford 1986.

Asa BRIgGs, The History of Broadcasting in the United Kingdom, sv. 1-5, Oxford 1961. - 1995.

Asa Briggs i Peter Burke, Socijalna povijest medija. Od Gutenberga do interneta, Zagreb 2011.

Ivo Graovac, „Fenomen Veco Holjevac“, u: Većeslav Holjevac: graditelj, vizionar, ratnik (ur. Juraj Hrženjak), Zagreb 2007.

Valentina Gulin Zrnić, Kvartovska spika. Značenje grada i urbani lokalizmi u Novom Zagrebu, Zagreb 2009.

Vedran Ivanković, „Arhitekt Vladimir Antolić - zagrebački urbanistički opus između dva svjetska rata“, Prostor, 17/2009., br. 2 (38), 269-283.

Zdenko Kolacio, „Problemi urbanističkog razvoja Zagreba“, Iz starog i novog Zagreba, sv. 3 (ur. Franjo Buntak), Zagreb 1963.

Iva Kraljević-BAšIĆ, „Matica iseljenika Hrvatske 1964.-1968.“, Časopis za suvremenu povijest, 41/2009., br. 1, 71-92. 
Željko Kuzmić, Poplava u Zagrebu 1964. godine, Zagreb 2004.

Kurt Lang i Gladys Engel Lang, Television and Politics, London 2002.

Josip Mihaljević, „Stota obljetnica rođenja Većeslava Holjevca (1917.-1970.)“, Zagreb moj grad, 11/2017., br. 64, 6-11.

Josip Minaljević, „Većeslav Holjevac - Forgotten Dissident“, Prispevki za novejšo zgodovino, 58/2018., br. 3, 128-147.

Povijest grada Zagreba, knj. 2: 20. i 21. stoljeće, Zagreb 2013.

Drago Roksandić, „Filozofski fakultet u poplavi 1964. godine: sjećanja i dokumenti“, Hrvatske vode, 18/2010., br. 73, 241-248.

Mirela Slukan Altić, „Povijest regulacije rijeke Save kod Zagreba i njene posljedice na izgradnju grada“, Hrvatske vode, 18/2010., br. 73, 205-212.

Katarina SpeHnjaK, „Većeslav Holjevac u političkim zbivanjima u Hrvatskoj 1967. godine“, Časopis za suvremenu povijest, 32/2000., br. 3, 567-593.

Tomislav Timet, „Prilog poznavanju stambene izgradnje Zagreba“, Iz starog i novog Zagreba, sv. 3 (ur. Franjo Buntak), Zagreb 1963.

Tomislav Timet, Stambena izgradnja Zagreba do 1954. godine. Ekonomsko-historijska analiza, Zagreb 1961.

Nikola Vončina, RTV Zagreb 1959. - 1964. Prilozi za povijest radija i televizije u Hrvatskoj IV, Zagreb 2001.

Nikola Vončına, TV osvaja Hrvatsku. Prilozi za povijest radija i televizije u Hrvatskoj III (1954. 1958.), Zagreb 1999.

\section{Mrežna stranica}

„Većeslav Holjevac“, Hrvatska enciklopedija (http://www.enciklopedija.hr/natuknica.aspx?id=25994) 
